\title{
MIXED FARMING AMONG HERDER HOUSEHOLDS IN NIGER STATE, NIGERIA
}

\author{
Madu Ali Bwala ${ }^{\varpi 1}$, Alhassan Mohammed Alhassan ${ }^{1}$, Adedeji Sharafadeen ${ }^{1}$ \\ ${ }^{1}$ Ibrahim Badamasi Babangida University, Lapai, Nigeria
}

\begin{abstract}
The notion that herder households only restrict their livelihood strategy to the rearing of livestock most often than not excludes the group from the right to access land for the agricultural activity they engage in. This study investigated the participation of herder households in sedentary agriculture (crop production) in Niger state, Nigeria. Findings from this study show that herder households in the study area are no longer strictly livestock keepers; they participate in crop production just like crop farmers who also combine the cultivation of crops with livestock keeping. The results also revealed that most herder households $(66 \%)$ that engage in crop production cultivate cereals; other crops cultivated by herder households in the study area include tuber crops $(22 \%)$ and vegetables. Regarding herder household farm outputs, most of the harvests are at the subsistence level, with the harvests ranging between $300 \mathrm{~kg}$ and $750 \mathrm{~kg}$. Identified drivers of herder households' participation in crop production include: duration of stay in a particular locality, increase in household size, economic motives (grain price), and reducing the dependence on crop farmers for food supply. Therefore, this study recommends that interest of herder households in cultivating crops be sustained and encouraged. The participation of herder households in crop production will enhance their own food security status in the first instance and throughout the area in general.
\end{abstract}

Keywords: herders, crop production, cereals and vegetables, participation drivers, households

\section{INTRODUCTION}

Herder households are known solely for the keeping of livestock as a livelihood strategy; their herd is predominantly cattle with a mix of sheep and goats (UNCHR, 2005; Degev, 2011; Samuel, 2013). This activity of herder families provides the much needed animal protein required for human sustenance in the country (Haruna and Murtala, 2005; Okello et al., 2014; Olusanya, et al., 2014). As participants in the agricultural sector, herder families were hitherto believed to restrict their agricultural activity to livestock production (Muhammed et al., 2015; Mbih et al., 2018). However, the trend has seemingly deviated from the norm. Nowadays, herder families are seen to take crop produce to markets for sale. Herder families may be seen hawking/selling vegetables such as pepper, okra, and tomatoes which are supposedly cultivated by them. Be it as it may, the sale of farm produce by the herders is sometimes ignorantly suspected to be the outcome of pilferage on farms owned by crop producers.

It is rather counterintuitive to observe that herder families also engage in crop production, and yet are most often alleged to encroach on farmlands to graze their livestock (Ofuoku and Isife, 2010). Such occurrence has culminated in conflicts between the herders and crop producers, which can be seen to severe their relationship. However, herders and crop farmers live on good terms with each other if both parties play by the rules. In time past, herders were known to sell livestock

\footnotetext{
$\bowtie$ Madu Ali Bwala, PhD, Department of Agricultural Economics and Extension Services, Ibrahim Badamasi Babangida University, PMB 11 Lapai, Niger State, Nigeria, e-mail: bwalamadu@yahoo.com, https://orcid.org/0000-0002-8914-9885
} 
products or barter it for the cereals they needed (Kervin, 1992). What could be the reason for the recent development in herder families' way of life? Do economic factors play a role? Or could it be as a result of lack of access to grazing land? Could it also be the consequence of settling in a particular location for a long time? Whatever the reason for the development, there is a linkage among the questions raised. Furthermore, it is interesting to note that the benefits from shifting to another livelihood strategy of herder households would also include attaining food security on the whole.

The need to be food secure may be an underlying factor for the participation of herder households in crop production. However, other social factors - such as reducing dependence on crop producers for food due to conflict — cannot be ruled out as well. The desire to increase income sources may also be a reason. While the reasons for the participation of herder households in crop production may be numerous and complex, this development may be a stage in the dynamic evolution of the operating pattern of local herder families. Therefore, this study assessed the prevalence of mixed farming among herder families with emphasis on the underlying causes, benefits and constraints.

\section{METHODOLOGY}

\section{Study area}

The study was carried out in Lapai and Bosso Local Government Areas of Niger state, Nigeria. Lapai and Bosso are located at the south and northeast of the senatorial district of Niger state, respectively. The state is populated mainly by the Nupe people in the south, the Gwari in the east, the Busa in the west, and Kamberi (Kambari), Hausa, Fulani, Kamuku and Dakarkari in the north. The state is known to have the largest arable land in the country.

\section{Method of data collection}

Data for the study was collected using a structured questionnaire. Respondents were sampled through a multistage random sampling method; two Local Government Areas located in the state (Lapai and Bosso) where initially selected. The second stage involved the selection of three (3) villages from each of the two Local Government Areas sampled. Finally, 20 herder households were sampled randomly from each of the six selected villages.

\section{Analytical method}

Descriptive statistics such as means and percentages were used to categorize and analyze the data. Furthermore, a chi-squared test was used to determine whether or not there is a relationship between participation level and drivers of participation.

The output $(\mathrm{kg})$ of crops cultivated was used to denote the level of participation by the herder households.

$$
x^{2}=\sum \frac{\left(O_{i}-E_{i}\right)^{2}}{E_{i}}
$$

where:

$O$ : observed frequency

$E$ : expected frequency

\section{Hypothesis}

This study verifies whether or not the level of production in the study area has any relationship with the identified drivers of herder participation in crop production. The null and alternative hypotheses are stated below:

Hypothesis:

$\mathrm{H}_{0}$ : there is no relationship between the level of production and participation drivers.

$\mathrm{H}_{1}$ : there is a relationship between the level of production and participation drivers.

\section{RESULT AND DISCUSSION}

\section{Socioeconomic characteristics of herders}

Education is a means to self-fulfillment through informed deployment of strategies that increase the chance of an individual to succeed in any endeavor. In this study, most (83\%) of the sampled respondents had no western education (Fig. 1). Furthermore, majority of the respondents had a Quranic and non-formal education. The above finding implies that this group of herder farmers cannot independently comprehend written information/instruction on fertilizers, herbicides and pesticides they may use in their farming operations. Furthermore, technology application may be a challenge due to lack of capacity. Hence, it is important for the relevant agencies, especially the nomadic education institutions, to intensify their efforts towards encouraging enrolment into schools by herder children. It is also interesting to observe that $23 \%$ of the respondents had a secondary education. This means that these individuals may enroll their children into schools as well, hence ensuring a multiplier effect. 


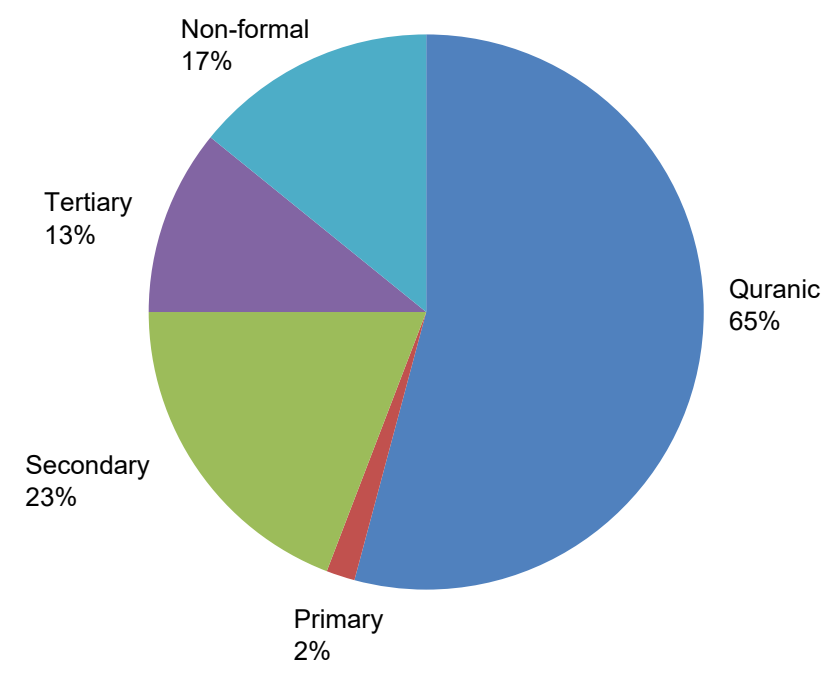

Fig. 1. Education level of herders

The study also observed that almost all herders sampled $(97.5 \%)$ engaged in crop production are male; furthermore, most of the herders $(48.4 \%)$ were found to be between 30-39 years old (Fig. 2).

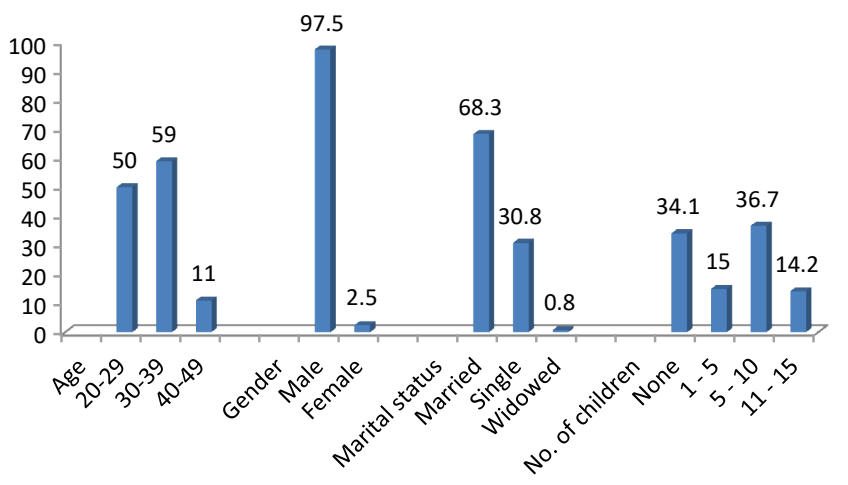

Fig. 2. Demographic attributes of respondents

This finding shows that crop production in the study area is mostly carried out by younger men who are very active and within the productive age group. The above can be explained by the fact that herder communities are male-dominated. Indeed, herding is carried out solely by men while women only engage in milking and tending to family needs, and so is the case with crop farming (FAO, 2001). Furthermore, this results from the interaction with the northern host communities where farm work is mostly carried out by men (Oseni et al., 2014). Regarding marital status, most herders interviewed were married, with most family sizes varying in the range of 5 to 10 individuals in a herder household. A large family is an asset to the farmer/agricultural practitioner because farm tasks are labor intensive and thus require considerable expenditure on labor. It is therefore a comparative advantage for large families to use family labor in carrying out farm tasks. The availability of family labor increases the profit margin of the enterprise and affords the family the wherewithal to embark on a larger-scale business.

Herder families are known for transhumance practices, which usually hinder them from engaging in any endeavor that requires one to be domiciled in a particular location over a long period. It is therefore important to find out for how long herder families have dwelled in a particular location. This will provide an insight into whether or not the duration of stay is a factor in the participation of such households in crop cultivation. Findings revealed that most $(91 \%)$ respondents have stayed in their current location for more than 10 years (Table 1). However, it is interesting to note that some of the herders move around with the herd while leaving their families behind. This finding is in line with the report from a study by Sodiya et al. (2009) who claim that herders known to migrate with their herds are now becoming sedentary. The host communities are farming settlements that the herders have been interacting with over time; the two groups have thus established a relationship.

Table 1. Residency and relationship of herder families with host communities

\begin{tabular}{lrr}
\hline \multicolumn{1}{c}{ Variable } & Frequency & Percentage \\
\hline Residency in the last ten years & & \\
Present location & 110 & 91.7 \\
Other locations & 10 & 8.3 \\
Total & 120 & 100.0 \\
Relationship with host community & & \\
Cordial & 116 & 96.7 \\
Mixed & 4 & 3.3 \\
Total & 120 & 100.0 \\
\hline
\end{tabular}

Source: field survey, 2018. 
Also, findings show that most $(96.7 \%)$ herder families have cordial relationships with their host communities (Table 1). However, a few reported a mixed cordial relationship with their host community; these are the cases where the individuals are experiencing or have experienced unpleasant incidences involving members of the host community.

Access to extension service is critical to the farmers because this is how they are enlightened about new technologies in agricultural practice. Therefore, access to extension contact brings farmers closer to upgraded or previously unavailable technologies. Observations from the study suggest that the majority $(88.3 \%)$ of herder households do not have contact with extension services (Fig. 3). The implication of this finding is that herder households would not be up to date with extension news and any useful information that may be of importance to their enterprise.

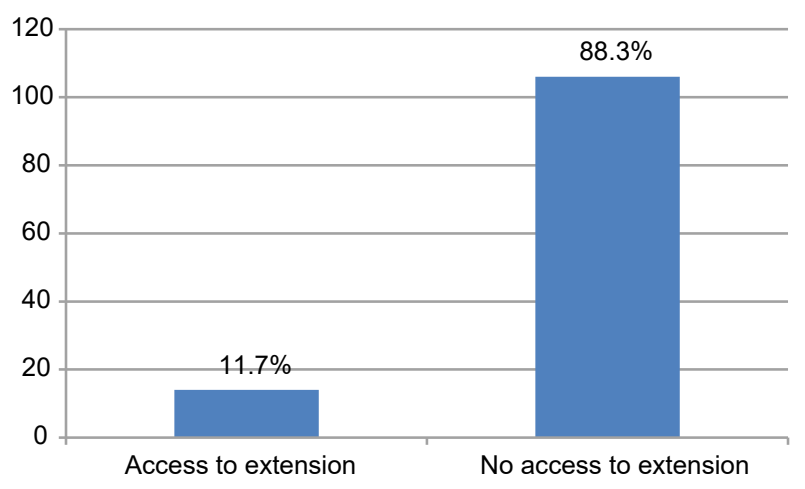

Fig. 3. Access to extension services

It therefore means that most of the crop farming knowledge used by the herder households was obtained through their interaction with crop farmers.

Farm size available to farmers for cultivation is usually a determining factor for the number of enterprises that can be ventured into. The income accruable to the farm venture is further determined by the number of enterprises pursued by the farmer. Efficient allocation of land among enterprises on the farm requires knowledge of soil requirements for the crop business to thrive. Considering the land sizes cultivated by herder households, it may be concluded that they engaged in the cultivation of not just one but several crops. The findings also show

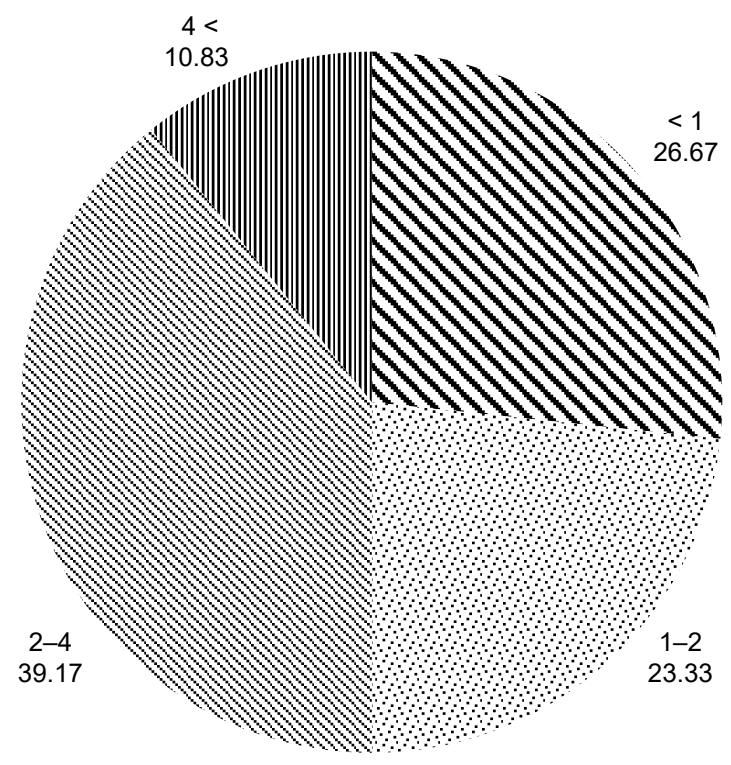

Fig. 4. Size of farms cultivated by herder households

that majority of the herder households have farm sizes varying in the range of two to four hectares (Fig. 4), followed by households that hold less than one hectare of land. This finding goes to show that herder households have ventured into the farming business to the same extent as the crop farmers that abound in the Nigeria's agricultural sector. Most farmers practicing agriculture in Nigeria are small-scale operators (Mgbenka et al., 2015).

\section{Drivers of participation in crop cultivation among herder households}

For any human endeavor, reasons abound for engagement or participation by individuals. In Africa and Nigeria specifically, agriculture is practiced at the subsistence level (Apata et al., 2011) because the industry is dominated by small farmers. Hence, the objective of participation in crop cultivation for this group of farmers is first of all to achieve sustenance. However, that does not negate the existence of individuals who engage in cultivation mainly for economic reasons, i.e. deliver all of their output to the market. What makes herder families deviate from the norm continues to be an open question. Against this backdrop, this study investigates the underlying reasons why herder families participate in crop production. Findings revealed that most respondents $(48.9 \%)$ participate in crop production because they have settled in an area for a long time. Settling in an area for a long period affords the herder families the 
Table 2. Drivers of herder households' participation in crop production

\begin{tabular}{lcc}
\hline \multicolumn{1}{c}{ Variable } & Frequency & $\begin{array}{c}\text { Percentage } \\
(\%)\end{array}$ \\
\hline Scarcity and high cost of food & 36 & 16.4 \\
Increase in household size & 51 & 23.3 \\
Higher returns from crop sales & 11 & 5.0 \\
Byproducts for feeding livestock & 1 & 0.5 \\
Scarcity of grazing land & 1 & 0.5 \\
Reduction of dependence on farmers & 10 & 4.6 \\
Farmer/herdsmen conflict & 1 & 0.5 \\
Permanent settlement & 107 & 48.9 \\
Availability of abundant land & 1 & 0.5 \\
Total* & 219 & 100.0 \\
\hline
\end{tabular}

*Multiple responses were allowed.

Source: field survey, 2018.

opportunity to take the advantage of the rainy season for cropping purposes. The results also show that a good number $(23.3 \%)$ participate in crop production because of an increase in their household size (Table 2). It is only reasonable to engage in the cultivation of land if it provides food for the family in a situation where purchasing such commodities becomes a challenge.

Furthermore, an increase in household size could also be the reason for herder families to settle permanently in an area. This is because as the household size increases, it is complicated to migrate and thus settling in a location becomes an attractive option. It can therefore be asserted that the main reason why herder families participate in cultivating crops is that they have settled permanently as a result of an increase in their household size. High grain price is also a factor contributing to the participation of herder households in crop production; though few (16.4\%) of the respondents indicated it as a reason for their engagement in crop production, it is a cogent reason for such households.

However, it is important to ponder whether this development is a result of economic challenges the households are facing with regard to provision of bare necessities of life. Be it as it may, the participation of herder families in crop production will be conducive to conflict with crop farmers as a result of grazing/cropping rights.
Having identified the reasons why herder households cultivate crops in the study area, it is important to further determine whether or not there is a relationship between the factors identified and the participation in food crop cultivation by herder households. Adopting the quantity of crop produced by herder households as a proxy for the level of participation, a chi-squared test was conducted for all identified drivers of participation and the level of participation for cereals and tubers. This was to ascertain whether or not there is a relationship between the identified drivers and the level of output obtained by the households. For all the drivers identified, an increase in household size, reduction in grazing land, reducing dependence on crop farmers for food and permanent settlement were significant for the level of participation in cereal cropping at five degrees of freedom (Table 3, 4, 5 and 6) The null hypothesis stating that there is no relationship between the drivers of participation and level of output is therefore rejected and the alternative accepted..

Table 3. Relationship between the increase in household size and cereal output

\begin{tabular}{lrrc}
\hline \multicolumn{1}{c}{ Analysis } & Value & df & $\begin{array}{c}\text { Asymp. sig. } \\
(2 \text {-sided })\end{array}$ \\
\hline Pearson's chi-squared & $84.418^{\mathrm{a}}$ & 61 & 0.025 \\
Likelihood ratio & 113.950 & 61 & 0.000 \\
Linear-by-linear association & 20.347 & 1 & 0.000 \\
No. of valid cases & 120 & & \\
\hline
\end{tabular}

${ }^{a} 123$ cells $(99.2 \%)$ have an expected count of less than 5 . The minimum expected count is 0.43 .

Source: field survey analysis, 2018.

Table 4. Relationship between dwindling grazing land and cereal output

\begin{tabular}{lccc}
\hline \multicolumn{1}{c}{ Analysis } & Value & df & $\begin{array}{c}\text { Asymp. sig. } \\
(2 \text {-sided })\end{array}$ \\
\hline Pearson's chi-squared & $1.200 \mathrm{E} 2^{\text {a }}$ & 61 & 0.000 \\
Likelihood ratio & 11.567 & 61 & 1.000 \\
Linear-by-linear association & .087 & 1 & 0.767 \\
No. of valid cases & 120 & & \\
\hline
\end{tabular}

${ }^{\mathrm{a}} 121$ cells $(97.6 \%)$ have an expected count of less than 5 . The minimum expected count is 0.01 .

Source: field survey analysis, 2018. 
Table 5. Relationship between reduction of dependence for food and cereal output

\begin{tabular}{lrrc}
\hline \multicolumn{1}{c}{ Analysis } & Value & df & $\begin{array}{c}\text { Asymp. sig. } \\
\text { (2-sided) }\end{array}$ \\
\hline Pearson's chi-squared & $13.276^{\mathrm{a}}$ & 5 & 0.021 \\
Likelihood ratio & 8.422 & 5 & 0.134 \\
Linear-by-linear association & .125 & 1 & 0.724 \\
No. of valid cases & 120 & & \\
\hline
\end{tabular}

a 8 cells $(66.7 \%)$ have an expected count of less than 5 . The minimum expected count is 0.08 .

Source: field survey analysis, 2018.

Table 6. Relationship between permanent settlement and cereal output

\begin{tabular}{lrcc}
\hline \multicolumn{1}{c}{ Analysis } & Value & df & $\begin{array}{c}\text { Asymp. sig. } \\
\text { (2-sided) }\end{array}$ \\
\hline Pearson's chi-squared & $9.344^{\mathrm{a}}$ & 5 & 0.096 \\
Likelihood ratio & 11.900 & 5 & 0.036 \\
Linear-by-linear association & 6.353 & 1 & 0.012 \\
No. of valid cases & 120 & & \\
\hline
\end{tabular}

a7 cells $(58.3 \%)$ have an expected count of less than 5 . The minimum expected count is 0.11 .

Source: field survey analysis, 2018.

However, only the household size and the prospects of higher returns were significant with respect to the level of participation of herder families in tuber cultivation (Table 7 and 8).

Table 7. Relationship between the increase in household size and tuber output

\begin{tabular}{lccc}
\hline \multicolumn{1}{c}{ Analysis } & Value & df & $\begin{array}{c}\text { Asymp. sig. } \\
\text { (2-sided) }\end{array}$ \\
\hline Pearson's chi-squared & $11.732^{\mathrm{a}}$ & 5 & 0.039 \\
Likelihood ratio & 12.252 & 5 & 0.031 \\
Linear-by-linear association & 8.131 & 1 & 0.004 \\
No. of valid cases & 120 & & \\
\hline
\end{tabular}

${ }^{\mathrm{a}} 6$ cells $(50.0 \%)$ have an expected count of less than 5 . The minimum expected count is 0.43 .

Source: field survey analysis, 2018.
Table 8. Relationship between higher returns and tuber output

\begin{tabular}{lccc}
\hline \multicolumn{1}{c}{ Analysis } & Value & df & $\begin{array}{c}\text { Asymp. sig. } \\
\text { (2-sided) }\end{array}$ \\
\hline Pearson's chi-squared & $28.678^{\mathrm{a}}$ & 5 & 0.000 \\
Likelihood ratio & 20.100 & 5 & 0.001 \\
Linear-by-linear association & 7.143 & 1 & 0.008 \\
No. of valid cases & 120 & & \\
\hline
\end{tabular}

a8 cells $(66.7 \%)$ have an expected count of less than 5 . The minimum expected count is 0.09 .

Source: field survey analysis, 2018.

It can therefore be asserted that herder households in the study area participate in crop cultivation due to an increase in their household size and because of dwindling grazing land. Other reasons identified were permanent settlement and the bid to reduce dependence on crop farmers for food. Also, the economic benefit (returns) from such venture are an encouragement to participate.

\section{Description of herder households' participation in crop production}

Herders and farmers have coexisted since time immemorial; their interactions include trade and transactions related to the replenishment of farm food stocks. Therefore, the interest among herder households in crop cultivation results from: the relationship that has for long been existing between the two parties; the duration of stay at a particular location; and family size. The choice of crop for cultivation may also provide an insight into what encourages participation in crop production. Furthermore, understanding the basis for the herder households' choice of crop for cultivation will provide guidance for possible intervention policies, or a basis for measures taken to address the challenges related to conflicts witnessed in the industry. The observation revealed that most herder households $(66 \%)$ which engage in crop production cultivate cereals (Fig. 5).

Farming knowledge exhibited by herders engaged in crop farming is evidently attributed to the fact that herders settled within and around crop farmer communities which facilitates transfer of knowledge/interest. Cereals constitute major staples cultivated by farmers and consumed by households in Nigeria. Grains such as maize, sorghum, millet etc. are used in the daily menu. The interest of herder households in cultivating cereals 


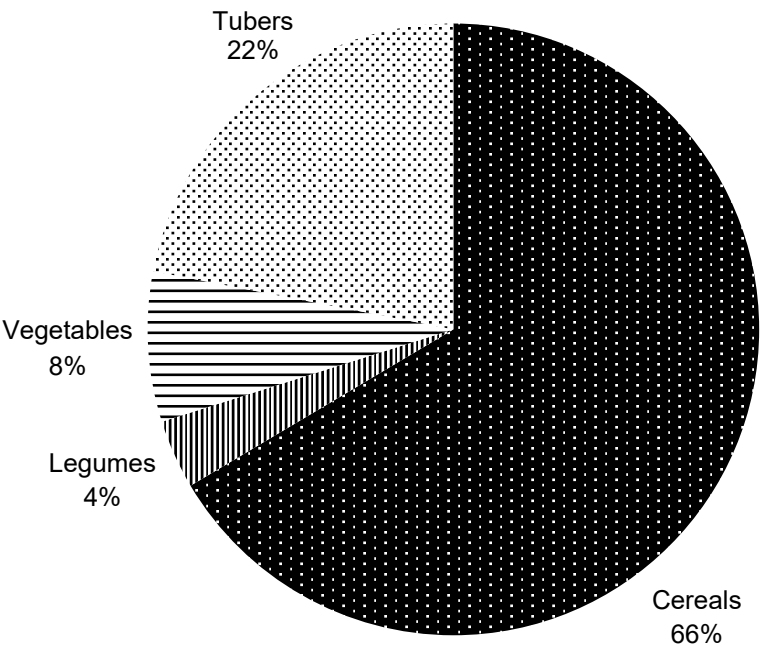

Fig. 5. Crop type cultivated by herder households

may not be isolated from the fact that the main objective for this strategy is to meet home consumption demands. This tendency is derived from the participation driver "permanent settlement" (Table 2). The next crop that attracts participation from herder households are tubers (22\%) followed by vegetables. Tubers serve both as food and cash crop because they sell at a good price on the market. This observation rather emphasizes the fact that herder households' participation in crop cultivation is far from casual. Indeed, the cultivation of tuber crops (especially yam) is labor-intensive at the onset and requires local technology usually adopted by the Gbagy. Hence, for the herder households to engage in the cultivation of a crop that involves such drudgery points to the fact that whatever the drive, the reason for participation is cogent.

Findings regarding years of participation in crop cultivation show that most respondents (48.3\%) have been cultivating crops for over 15 years, while a good number fall within the period of 6 to 15 years (Table 9). The duration of the herder households' crop cultivation activities will definitely impact their cultivation practices. Experience acquired over the years should be reflected in the farm management strategy of herder households. The strategy, in turn, may be observed to affect labor and enterprise selection decisions: the herders cultivate several crops which is indicative of diversification in their crop production base. The use of modern inputs is expedient in the achievement of a profitable farm venture, be it labor saving, nutrient enhancement or protection against pest and diseases; modern agriculture has a solution to the challenge.

The use of modern inputs by herder families in their agricultural practice is a pointer to how much they appreciate crop cultivation and are willing to face the associated challenges. The results show that herder households use technology in all areas of challenge in agriculture, i.e. nutrient supplements, weeds, pest and diseases. The results show that most respondents $(51.4 \%)$ use herbicides while only $12.0 \%$ use pesticides (Table 9). However, pesticides are used mainly by legume farmers. Furthermore, the use of fertilizers is not common among the herders as revealed by just $36.6 \%$ of the respondents indicating fertilizer usage. It is worthy of note that those who use chemical fertilizers do so because their hold a small herd or their cattle is grazing far away from home. Hence, for the majority of the herders, cattle dung is the main source of crop nutrient.

Herder households' participation in crop cultivation can be said to modify their relationships with crop farmers. This is evident in the fact that as herder households cultivate crops they are inadvertently reducing their reliance on farmers for food and fodder supply.

Table 9. Participation experiences incurred and modern inputs used in crop production by herder households

\begin{tabular}{lcc}
\hline \multicolumn{1}{c}{ Variables } & Frequency & $\begin{array}{c}\text { Percentage } \\
(\%)\end{array}$ \\
\hline Farming experience (years) & & \\
less than 5 & 16 & 13.3 \\
$6-15$ & 46 & 38.4 \\
$16-20$ & 22 & 18.3 \\
over 20 & 36 & 30.0 \\
Total & 120 & 100.0 \\
Use of modern inputs & & \\
fertilizer & 79 & 36.6 \\
herbicide & 111 & 51.4 \\
pesticide & 26 & 12.0 \\
Total* & 216 & 100.0 \\
\hline
\end{tabular}

*Multiple responses were allowed. Source: field survey, 2018. 
But does this development also mean that manure use by crop farmers on the farm is also on the decline because herders now can use their cattle dung? Hitherto the practice was to agree on a quantity of grain to be supplied by the crop farmer to the herder. In exchange, cattle stayed on the farm land for a particular period during which it was expected that the land would be fertilized by cattle dung.

\section{Output obtained from crop production by herder households}

Herder households no longer exchange livestock for food or grazing rights. This is because they are now involved in the cultivation of what they need for household consumption; as a result, their livestock enjoy the benefit of grazing the farmlands after harvest and thus do not travel long distances for dry season grazing. Findings from this study show that most harvests are at the subsistence level, varying in the range of $300 \mathrm{~kg}$ to $750 \mathrm{~kg}$ (Table 10).

Tuber cultivation is increasingly gaining recognition from herder households living close to/among Gbagy communities. The participation of herder households in yam cultivation indicates the extent to which the households are involved in crop production. This is because yam production is a specialty of the Gbagy tribe living in the study area. Not all farmers venture into yam production due to the complexity associated with its cultivation. Hence, yam cultivation by herder households is an indicator of their expertise in and commitment to crop production as an outcome of their interaction with the Gbagy tribe. Crop cultivation by herder households clearly reflects an effort at reducing dependence on farmers for food and feed. Be it as it may, this could be a solution to the incessant conflicts with the farmers. This is because as herder families permanently settle in communities, invasion into farm land by cattle may be reduced because of the working relationship that has been established. Furthermore, when explored and addressed by a policy, a change/modification in the livelihood strategy of herder households could provide a basis for intervention in an amicable resolution of conflicts between the two players in the agricultural industry. As stated earlier, the purpose of herders' crop production is consumption rather than sale, and therefore they sell small quantities of their produce.

The availability of market surplus generated by farmers (be it livestock or crops) indicates whether or not
Table 10. Output of herder households from crop production

\begin{tabular}{|c|c|c|}
\hline Variable & Frequency & $\begin{array}{c}\text { Percentage } \\
(\%)\end{array}$ \\
\hline \multicolumn{3}{|l|}{ Cereals (kg) } \\
\hline 300 & 34 & 28.3 \\
\hline 750 & 47 & 39.2 \\
\hline 600 & 23 & 19.2 \\
\hline 1500 & 3 & 2.5 \\
\hline 3750 & 1 & 0.8 \\
\hline none & 12 & 10.0 \\
\hline Total & 120 & 100.0 \\
\hline \multicolumn{3}{|l|}{ Tubers } \\
\hline less than 600 & 15 & 12.5 \\
\hline 1200 & 13 & 10.8 \\
\hline 1800 & 4 & 3.3 \\
\hline 2400 & 1 & 0.8 \\
\hline over 3000 & 5 & 4.2 \\
\hline none & 82 & 68.3 \\
\hline Total & 120 & 100.0 \\
\hline \multicolumn{3}{|l|}{ Market surplus } \\
\hline available & 22 & 18.3 \\
\hline not available & 78 & 81.7 \\
\hline Total & 120 & 100.0 \\
\hline \multicolumn{3}{|l|}{ Income from sales of tubers } \\
\hline less than NGN 50,000 & 13 & 5.8 \\
\hline NGN 51,000-100,000 & 1 & 0.8 \\
\hline NGN 101,000-150,000 & 1 & 0.8 \\
\hline over NGN 150,000 & 7 & 5.8 \\
\hline none & 78 & 81.7 \\
\hline Total & 120 & 100.0 \\
\hline
\end{tabular}

Source: field survey, 2018.

such endeavor contributes to farming incomes, which most often provide a basis for assessing the farmers' welfare. This is because the availability of market surplus provides the farmers with funds to purchase other commodities not produced by them but needed for the wellbeing of the household (Bwala and Tiamiyu, 2015). 
This study observed that while herder households produce to meet home consumption needs, they also have a certain quantity of products to sell at the market (market surplus).

\section{CONCLUSION}

The characterization of herder households is important in defining the role they play in agricultural development in Nigeria. Hence, in order to be properly understood, their contribution to the Nigerian economy needs to be looked at from the right perspective. Findings from this study show that herder households are no longer strictly livestock keepers; they participate in crop production just like crop farmers who also combine the cultivation of crops with livestock keeping. Hence, herder households contribute to achieving food security with regard to the availability of grains; this is buttressed by the fact that such households do have a market surplus for sale after their home consumption needs are met. Interest in crop production from herder households is expedient for the industry as their participation will contribute to creating and exploiting avenues for developmental engagements. Therefore, this study recommends that interest of herder households in cultivating crops be sustained and encouraged. This is because the combination of livestock and crop production enhances the resilience of such households by providing them with management strategies against risks.

\section{REFERENCES}

Apata, T. G., Folayan, A. Apata, O. M., Akinlua, J. (2011). The Economic Role of Nigeria's Subsistence Agriculture in the Transition Process: Implications for Rural. 85th Annual Conference of the Agricultural Economics Society Warwick University.

Bwala, M. A., Tiamiyu, S. A. (2015). Determinants of Market Surplus Availability of Cereal Crops Among Farm Households in North Central Nigeria. Niger. Agric. J., 46(1\&2).

Degev, A. A. (2011). Transformation of Borana from nomadic patoralisme to agropastoralists and shift of livestock from cattle to include more goats, camels and sheep in southern Ethiopia. Int. J. Bus. Glob., 6, 3-4.

FAO (2001). Pastoralism in the new millennium: FAO animal production and health paper 150. Rome: Food and Agricultural Organization.
Gefu, J. O., Kolawole A. (2002). Conflict in common property resource use: experiences from an irrigation project. Paper prepared for 9th conference of the international association for the study of common property. Indiana.

Haruna, U., Murtala, N. (2005). Commodity chain analysis of cattle marketing in Nigeria; A case study of K.R.I.P. Area of Kano State A Report Submitted to Adeni project/ NAERLS ZARIA. 38p.

Kervin, C. (1992). Customary Commerce: A Historical Reassessment of Pastoral Livestock Marketing in Africa. Published by the Overseas Development Institute, Regent's College, Inner Circle, Regent's Park, London NW1 4NS. Russell Press Ltd, Nottingham.

Mbih, R. A., Driever, S. L., Ndzeidze, S. K. Mbuh, M. J., Bongadzem, C. S., Wirngo, H. M. (2018). Fulani pastoralists' transformation process: a sustainable development approach in the Western Highlands of Cameroon. Env. Dev. Sust., 20(2), 789-807.

Mgbenka, N. R., Mbah, E., Ike, E. (2015). A Review of Small holder Farming in Nigeria: Need for Transformation. Agric. Eng. Res. J., 5(2), 19-26.

Muhammed, I., Ismaila, A. B., Bibi, U. M. (2015). An assessment of farmer-pastoralist conflict in Nigeria using GIS 1. Int. J. Eng. Sci. Invent., 4(7), 23-33.

Ofuoku, A. U., Isife, B. I. (2010). Causes, Effects And Resolution Of Farmers-Nomadic Cattle Herders Conflict In Delta State, Nigeria. Agric. Trop. Subtrop., 43(1), 33-41.

Okello, A. L., Majekodunimi, A. O., Malala, A., Welburn, S. C., Smith, J. (2014). Identifying motivators for state pastoralist dialogue: Exploring the relationship between livestock services, self-organization and conflict in Nigeria's pastoralist Fulani. Res. Policy Pract., 4 (12).

Olusanya, T. P., Fabusoro, E., Talabi, A. O. (2014). Involvement of Fulani agro-pastoralists in livestock marketing in Ogun state, Nigeria. Int. J. Edu. Res., 2(9), 297-306.

Oseni, G., Corral, P., Goldstein, M., Winters, P. (2014). Explaining Gender Differentials in Agricultural Production in Nigeria The World Bank Group. Africa Region Gender Practice Policy Brief. Issue 6.

Sodiya, C. I., Adedire, M. O., Lawal-Abebowale, O. A. (2009). Land holding rights of Fulani pastoralists and its effect on their Agro-pastoral production system in Ogun State, Nigeria. Tropicultura, 27(2), 65-69.

Samuel, T. (2013). From cattle herding to sedentary agriculture: the role of Hamer women in the transition. African Study Monographs, Suppl. 46, 121-133.

UNCHR (2005). Livestock-keeping and animal husbandry in refugee and returnee situation (A practical Handbook for Improved Management). Geneva. 